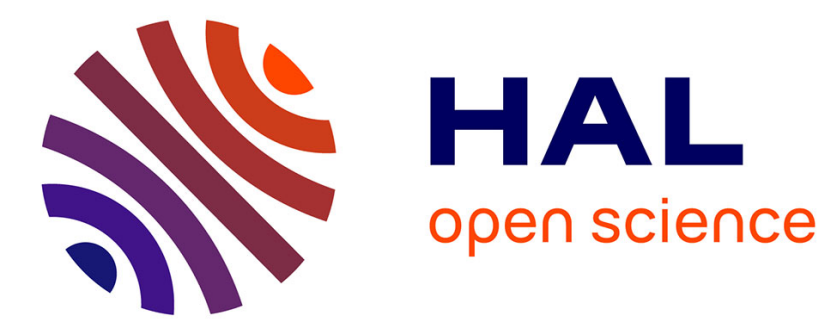

\title{
Synthesis and structure of a new organometallic polyoxomolybdate, $\mathrm{Cp}{ }^{*} 2 \mathrm{Mo} 6 \mathrm{O} 17$
}

Edmond Collange, Laurent Metteau, Philippe Richard, Rinaldo Poli

\section{To cite this version:}

Edmond Collange, Laurent Metteau, Philippe Richard, Rinaldo Poli. Synthesis and structure of a new organometallic polyoxomolybdate, Cp*2Mo6O17. Polyhedron, 2004, 23 (17), pp.2605-2610. 10.1016/j.poly.2004.06.025 . hal-03278419

\section{HAL Id: hal-03278419 https://hal.science/hal-03278419}

Submitted on 7 Jul 2021

HAL is a multi-disciplinary open access archive for the deposit and dissemination of scientific research documents, whether they are published or not. The documents may come from teaching and research institutions in France or abroad, or from public or private research centers.
L'archive ouverte pluridisciplinaire HAL, est destinée au dépôt et à la diffusion de documents scientifiques de niveau recherche, publiés ou non, émanant des établissements d'enseignement et de recherche français ou étrangers, des laboratoires publics ou privés. 
Synthesis and structure of a new organometallic polyoxomolybdate, $\mathrm{Cp}_{2}{ }_{2} \mathrm{Mo}_{6} \mathrm{O}_{17}$

Edmond Collange, ${ }^{\mathrm{a}}$ Laurent Metteau, ${ }^{\mathrm{a}}$ Philippe Richard ${ }^{\mathrm{a}}$ and Rinaldo Poli*a,b

${ }^{a}$ Laboratoire de Synthèse et d'Electrosynthèse Organométalliques, Faculté des Sciences

"Gabriel", Université de Bourgogne, 6 Boulevard Gabriel, 21000 Dijon, France

${ }^{\mathrm{b}}$ Laboratoire de Chimie de Coordination, UPR CNRS 8241, 205 Route de Narbonne, 31077

Toulouse Cedex, France.

Proofs to:

Rinaldo Poli

Tel: $+33-561333195$

Fax: $+33-561553003$

E-mail: poli@lcc-toulouse.fr 


\section{Summary}

Acidic aqueous solutions of the $\left[\mathrm{Cp}^{*} \mathrm{MoO}_{2}\left(\mathrm{H}_{2} \mathrm{O}\right)_{\mathrm{x}}\right]^{+}$ion yield single crystals of the novel organometallic polyoxomolybdate $\mathrm{Cp}^{*}{ }_{2} \mathrm{Mo}_{6} \mathrm{O}_{17}$ via a slow protonolysis of the Mo-Cp* bond. This compound has subsequently been obtained selectively and in good yields from the combination of $\mathrm{Cp}^{*}{ }_{2} \mathrm{Mo}_{2} \mathrm{O}_{5}$ and four equivalents of $\mathrm{MoO}_{4}{ }^{2-}$ under acidic conditions. The $\mathrm{X}-$ ray structure of $\mathrm{Cp}^{*}{ }_{2} \mathrm{Mo}_{6} \mathrm{O}_{17}$ is isotypic with other hexanuclear polyoxometallate ions but is the most distorted so far reported according to the continuous symmetry measure, the inner $\left(\mu_{6}-\mathrm{O}\right) \mathrm{Mo}_{6}$ core featuring a large displacement of the central oxygen atom toward the organometallic moieties and away from the inorganic ones.

Keywords: molybdenum, polyoxometallate, aqueous organometallic chemistry, pentamethylcyclopentadienyl ligands 


\section{Introduction}

We have recently initiated a research programme aimed at exploiting the chemistry of high oxidation state organometallic compounds in water. Aqueous organometallic chemistry is attracting growing interest because of its "green" impact ${ }^{[1-3]}$ and because of its promise in catalytic $^{[4,5]}$ and biomedical applications. ${ }^{[6]}$ Its development, however, has so far been restricted for the most part to low-valent systems to which hydrophilic functionalities are added on the ligand periphery, ${ }^{[7-9]}$ in order to make the systems compatible with an aqueous environment. High oxidation organometallics are now a well established family of compounds, ${ }^{[10,11]}$ mostly supported by oxo ligands. Pioneering work in this area was carried out by M. L. H. Green, with the now 40-year old synthesis and subsequent investigations of $\mathrm{Cp}_{2} \mathrm{Mo}_{2} \mathrm{O}_{5}{ }^{[12,}{ }^{13]}$ Some of these high oxidation state organometallic compounds exhibit interesting catalytic applications. ${ }^{[14]}$ Nonetheless, their investigation has so far mostly involved the use of organic solvents and very little is known about their behaviour in water. The investigation of these materials in water, especially for electroactive metals, offers opportunities for the development of new catalytic and electrocatalytic processes. ${ }^{[15]}$ Our first studies have focused on the speciation ${ }^{[16]}$ and on the electrochemical ${ }^{[17,18]}$ and chemical ${ }^{[19,20]}$ reduction behavior of the $\mathrm{Cp} * \mathrm{Mo}^{\mathrm{VI}}$ moiety. In particular, we have established that the $\mathrm{Cp}^{*} \mathrm{Mo}^{\mathrm{VI}}$ species is stable in air and in the entire $\mathrm{pH}$ range in a mostly aqueous medium $(80 \%$ $\mathrm{H}_{2} \mathrm{O}, 20 \% \mathrm{MeOH}$ ), at least for the time necessary to carry out the speciation studies (several hours at room temperature). While the species is stable in the form of the previously known ${ }^{[21-23]} \mathrm{Cp}^{*} \mathrm{MoO}_{3}{ }^{-}$complex at high $\mathrm{pH}$, its nature changes to the hitherto unknown cationic complex $\mathrm{Cp}^{*} \mathrm{MoO}_{2}\left(\mathrm{H}_{2} \mathrm{O}\right)_{\mathrm{x}}{ }^{+}$at very low $\mathrm{pH}(<\mathrm{ca} .2) .{ }^{[16]}$ For the latter species, the hydration status (e.g. whether it contains a coordinated water molecule or not) could not be determined from its spectroscopic characteristics (UV-visible) nor from its reactivity (kinetics 
of proton transfer processes). We have therefore attempted to obtain this information from a single crystal X-ray study. The outcome of these attempts have led to the chemistry which is described herein.

\section{Experimental Section}

General Part. Compound $\mathrm{Cp}^{*}{ }_{2} \mathrm{Mo}_{2} \mathrm{O}_{5}$ was prepared as described previously. ${ }^{[24]}$ The infrared spectra were recorded on a Brucker Vector 22 instrument equipped with a Globar (MIR) source. The powder X-ray diffraction spectrum was recorded with a Seifert XRD3000 $\theta / 2 \theta$ diffractometer using $\mathrm{Cu}$ radiation at $40 \mathrm{KV}$ and $30 \mathrm{~mA}$ and equipped with a graphite monochromator. The elemental analysis was carried out by the analytical services of LSEO with Fisons EA 1108 instruments.

Procedure leading to single crystals of $\mathbf{C p}_{2} \mathbf{M o 6}_{17}$. To a $\mathrm{MeOH}$ solution $(2 \mathrm{~mL})$ of $\mathrm{Cp}^{*}{ }_{2} \mathrm{Mo}_{2} \mathrm{O}_{5}(37 \mathrm{mg})$ was added $2 \mathrm{~mL}$ of aqueous $\mathrm{HNO}_{3}(0.2 \mathrm{M})$ in air. This solution was transferred into a $50 \mathrm{~mL}$ Schlenk tube and the oxygen was removed by argon bubbling. The solution was subsequently left undisturbed on the bench. Brown crystals were obtained over a 2.5 month period. One of these crystals was used for the X-ray diffraction analysis.

Synthesis of $\mathbf{C p}_{2}{ }_{2} \mathrm{Mog}_{6} \mathrm{O}_{17} . \mathrm{Cp}_{2}{ }_{2} \mathrm{Mo}_{2} \mathrm{O}_{5}(54 \mathrm{mg}, 0.1 \mathrm{mmole})$ was dissolved in $2.5 \mathrm{~mL}$ of $\mathrm{MeOH}$. Separately, $\mathrm{Na}_{2} \mathrm{MoO}_{4} \cdot 2 \mathrm{H}_{2} \mathrm{O}(96.8 \mathrm{mg}, 0.4 \mathrm{mmole})$ was dissolved in $2.5 \mathrm{~mL}$ of water. The two solutions were mixed with no apparent change. $1 \mathrm{~mL}$ of $\mathrm{HNO}_{3} 0.1 \mathrm{M}$ was slowly added, forcing the immediate precipitation of an orange solid. The solid was filtered, washed with $\mathrm{H}_{2} \mathrm{O}$, then with $\mathrm{MeOH}$, and finally dried at $70{ }^{\circ} \mathrm{C}$. (Yield $86.5 \mathrm{mg}, 77.4 \%$ ). Anal. Calcd. for $\mathrm{C}_{20} \mathrm{H}_{30} \mathrm{Mo}_{6} \mathrm{O}_{17}$ : C, 21.48; H, $2.70 \%$. Found: C, 21.46; H, 2.91\%. IR (Nujol mull, $\mathrm{cm}^{-1}$ ): 978 w, 966 s, ca. 820 sh, 792 s, ca. 770 sh. 
Single crystal X-ray diffraction study. Intensities were collected on an Enraf-Nonius KappaCCD diffractometer at $110 \mathrm{~K}$ using Mo K $\alpha$ radiation. The structure was solved via a Patterson search program ${ }^{[25]}$ and refined with full-matrix least-squares methods ${ }^{[26]}$ based on $\left|\mathrm{F}^{2}\right|$ with the aid of the WINGX program. ${ }^{[27]}$ All non-hydrogen atoms were refined with anisotropic thermal parameters. Hydrogen atoms were included with a riding model with isotropic temperature factors fixed to 1.5 times those of the corresponding parent atoms. The essential crystallographic parameters are listed in Table 1 and selected bond distances and angles are collected in Table 2.

$<$ Table 1 and Table 2 here>

\section{Results}

According to our recent investigation, ${ }^{[16]}$ adjusting the $\mathrm{pH}$ of a $4: 1 \mathrm{H}_{2} \mathrm{O}-\mathrm{MeOH}$ solution of $\mathrm{Cp}^{*}{ }_{2} \mathrm{Mo}_{2} \mathrm{O}_{5}$ to $<2$ selectively generates the new oxo cation $\mathrm{Cp} * \mathrm{MoO}_{2}\left(\mathrm{H}_{2} \mathrm{O}\right)_{\mathrm{x}}{ }^{+}$, where the most likely values of $\mathrm{x}$ are 0 and 1 . In order to verify the presence of coordinated water in this complex, an acidic aqueous solution of $\mathrm{Cp}^{*} \mathrm{MoO}_{2}\left(\mathrm{H}_{2} \mathrm{O}\right)_{\mathrm{x}}{ }^{+}$was set out for a long term crystallization, as described in the Experimental Section. Salts of various anions such as $\mathrm{PF}_{6}{ }^{-}$ or $\mathrm{BPh}_{4}^{-}$were used, but the procedure typically led to the recovery of crystals of the neutral starting complex, $\mathrm{Cp}^{*}{ }_{2} \mathrm{Mo}_{2} \mathrm{O}_{5}$. A longer scale crystallization attempt, carried out without added salt, slowly yielded single crystals of a new compound. This turned out to correspond to the title organometallic polyoxometallate.

The title compound is a new member of the family of organometallic polyoxometallates. $^{[28]}$ Once the chemical nature of this compound was revealed by a single crystal X-ray diffraction study (vide infra), a more logical, selective and high yield synthesis 
was conceived, as illustrated in Equation 1. Mixing a methanolic solution of the organometallic reagent with an aqueous solution of the inorganic reagents in the appropriate stoichiometry yields a clear solution, from which the desired product rapidly precipitates upon acidification in an analytically pure form. The compound is sparingly soluble in water and only slightly soluble in organic solvents. Unlike the previously reported $\left[\mathrm{Cp}^{*} \mathrm{Mo}_{6} \mathrm{O}_{18}\right]^{-}$ analogue, ${ }^{[29,30]}$ its solubility in $\mathrm{MeCN}$ or DMSO at temperatures up to $80^{\circ} \mathrm{C}$ was not sufficient to allow the recording of ${ }^{95} \mathrm{Mo}$ or ${ }^{17} \mathrm{O}$ solution NMR spectra. However, the identity of the bulk sample as obtained from reaction 1 was established by the excellent match of its experimental powder X-ray diffraction pattern with the pattern calculated from the single crystal X-ray data, see Figure 1 and Table 3.

$<$ Figure 1 and Table 3 here>

$$
\mathrm{Cp}_{2}{ }_{2} \mathrm{Mo}_{2} \mathrm{O}_{5}+4 \mathrm{MoO}_{4}{ }^{2-}+8 \mathrm{H}^{+} \longrightarrow \mathrm{Cp}_{2}{ }_{2} \mathrm{Mo}_{6} \mathrm{O}_{17}+4 \mathrm{H}_{2} \mathrm{O}
$$

The single crystal X-ray analysis shows that the molecule is hexanuclear with the six Mo atoms placed at the vertices of an octahedron, see Figure 2. Each of the twelve octahedron edges is bridged by an oxygen atom. Four more oxygen atoms are placed on as many Mo atoms in the terminal coordination mode, while the remaining two cis-Mo atoms are $\eta^{5}$-bonded to $\mathrm{Cp} *$ ligands. The structure is completed by an additional oxygen atom, placed near the center of the octahedron. The molecule sits on a crystallographic twofold axis, which contains the central $\mathrm{O}(1)$ and the edge-bridging $\mathrm{O}(5)$ and $\mathrm{O}(8)$ atoms. The molecular geometry is identical with that of the previously published tungsten analogue, $\mathrm{Cp}^{*}{ }_{2} \mathrm{~W}_{6} \mathrm{O}_{17}$, including the relative cis- arrangement of the two $\mathrm{Cp}^{*}$-substituted metal atoms. ${ }^{[31]}$ The geometry can also be related to those of the $\left[\mathrm{Mo}_{6} \mathrm{O}_{19}\right]^{2-}$ and $\left[\mathrm{Cp}^{*} \mathrm{Mo}_{6} \mathrm{O}_{18}\right]^{-}$complexes, ${ }^{[29,30,32-}$ 
${ }^{34]}$ with which it can be considered isoelectronic and isostructural in light of the isolobal analogy between the terminal $\mathrm{Cp}^{*-}$ and $\mathrm{O}^{2-}$ ligands.

$<$ Figure 2>

Selected bond distances and angles are listed in Table 2. The terminal Mo-O distances average 1.685(3) $\AA$, which compares with 1.681(8) $\AA$ for $\left[\mathrm{Mo}_{6} \mathrm{O}_{19}\right]^{2-}$ (average over 14 different structures containing this ion available on the CCDC) and with 1.686(11) or 1.66(3) $\AA$ in the two different salts of $\left[\mathrm{Cp}^{*} \mathrm{Mo}_{6} \mathrm{O}_{18}\right]^{-} .{ }^{[29,30]}$ The edge-bridging Mo-O distances are longer and spread in a rather wide range between $1.855(3)$ and 2.029(3) A, showing a certain degree of asymmetry for the octahedral framework, similar to what is commonly found for other polyoxometallate ions. ${ }^{[29,35]}$ Their overall average is $1.93(6) \AA$, whereas the same average over the 14 different structures of the $\left[\mathrm{Mo}_{6} \mathrm{O}_{19}\right]^{2-}$ ion in the CCDC is $1.93(3) \AA$. There is no clear trend depending on the nature of the Mo atom (i.e. inorganic or organometallic). For instance, atoms $\mathrm{O}(2)$ and $\mathrm{O}(3)$ are closer to the inorganic Mo atom [1.855(3) and 1.883(3) $\AA$ ] than to the organometallic Mo atom [2.029(3) and 1.955(3) $\AA$, whereas the reverse is true for atom $\mathrm{O}(6)[1.980(3) v s .1 .890(3) \AA]$. The $\mathrm{O}$ atoms bridging two $\mathrm{Mo}(=\mathrm{O})$ units $[\mathrm{O}(4), \mathrm{O}(8)$ and $\mathrm{O}(10)]$ also show distances in a relatively wide range [from 1.861(3) to 2.006(3) $\AA$ ]. The highest degree of asymmetry, however, is exhibited for the $\mu_{6}-\mathrm{O}$ atom. The distances are shorter for the $\mathrm{Mo}(1)$ atom, 2.145(2) $\AA$, intermediate for the $\operatorname{Mo}(2)$ atom [i.e. cis to $\operatorname{Mo}(1)], 2.3674(5) \AA$, and longer from the $\operatorname{Mo}(3)$ atom [i.e. trans to Mo(1)], 2.542(3) A. A similar, though slightly less pronounced asymmetry was noted for the $\left[\mathrm{Cp}^{*} \mathrm{Mo}_{6} \mathrm{O}_{18}\right]^{-}$ion, where the Mo- $\left(\mu_{6}-\mathrm{O}\right)$ distances in the two independently determined structures $^{[29,30]}$ are 2.134(9) or 2.14(1) $\AA$ to the Cp*Mo atom, 2.343(9) or 2.33(2) $\AA$ to the cisMo atoms, and 2.498(9) or 2.48(1) $\AA$ to the trans-Mo atom. By comparison, the central 
oxygen is placed symmetrically in the $\left[\mathrm{Mo}_{6} \mathrm{O}_{19}\right]^{2-}$ ion, the average over the 14 structures available in the CCDC being 2.318(7) $\AA$. The use of the quantitative "octahedral symmetry measure", as defined by Avnir and Alvarez, ${ }^{[36,37]}$ for the title compound and for the related Cp*-containing polyoxometallates shows that the distortion of the $\left(\mu_{6}-\mathrm{O}\right) \mathrm{M}_{6}$ core is systematically and significantly larger than the distortion of the $\mathrm{M}_{6}$ core and that it is larger for compounds with two $\mathrm{Cp}^{*}$ substituents than for those with one. The distortion parameter for the $\left(\mu_{6}-\mathrm{O}\right) \mathrm{M}_{6}$ core is by far the largest $(0.172)$ for the title compound $(c f .0 .099$ for $\mathrm{Cp}^{*}{ }_{2} \mathrm{~W}_{6} \mathrm{O}_{17}, \quad 0.073$ and 0.066 for the two salts of $\left[\mathrm{Cp}^{*} \mathrm{Mo}_{6} \mathrm{O}_{18}\right]^{-}$, and 0.030 for $\left.\left[\mathrm{Cp}^{*} \mathrm{TiMo}_{5} \mathrm{O}_{18}\right]^{3-}\right)$. The displacement of the oxygen atom from the octahedron center was previously interpreted in terms of a stronger trans influence by the terminal oxo ligand relative to the terminal $\mathrm{Cp}^{*}$ ligand. It is possible, however, to provide an alternative rationalization in terms of the greater donor power of the terminal $\mathrm{O}^{2-}$ ligand with respect to the terminal $\mathrm{Cp}^{*-}$ ligand. Thus, the hypothetical $\mathrm{Cp}^{*}{ }_{2} \mathrm{Mo}_{6} \mathrm{O}_{16}{ }^{+}$moiety that is obtained by removal of the central $\mathrm{O}^{2-}$ ion would feature a lower electron density for the organometallic Mo atoms. The internal $\mathrm{O}$ atom is consequently attracted to a greater extent by these atoms. The metal distance from the $\mathrm{Cp}^{*}$ ring centroid, 2.109(4) $\AA$, compares with 2.091(15) $\AA$ in the $\left[\mathrm{Cp}^{*} \mathrm{Mo}_{6} \mathrm{O}_{18}\right]^{-}$structure.

\section{Discussion}

The result of the previous aqueous speciation study of the $\mathrm{Cp}^{*} \mathrm{Mo}^{\mathrm{VI}}$ moiety seemed to suggest that the $\mathrm{Cp}^{*}-\mathrm{Mo}^{\mathrm{VI}}$ bond is stable in an aqueous environment and in air in the entire $\mathrm{pH}$ range. Attempts to grow crystals of salts of the sought acidic $\mathrm{Cp} * \mathrm{MoO}_{2}\left(\mathrm{H}_{2} \mathrm{O}\right)_{\mathrm{x}}{ }^{+}$species, and the consequent formation of the organometallic polyoxomolybdate compound $\mathrm{Cp}{ }_{2} \mathrm{Mo}_{6} \mathrm{O}_{17}$, show that this is not quite so true. It should be remarked, however, that the 
crystals formed over an extended period of time (over two months), at $\mathrm{pH} \mathrm{1,} \mathrm{and} \mathrm{in} \mathrm{direct}$ summertime sunlight. This proves that the hydrolytic sensitivity of the $\mathrm{Cp}^{*}-\mathrm{Mo}^{\mathrm{VI}}$ bond is not a marked one. Therefore, the possible use the $\mathrm{Cp}^{*} \mathrm{Mo}^{\mathrm{VI}}$ species for catalytic applications in an aqueous environment at low $\mathrm{pH}$ remains promising.

Several other attempts to crystallize salts of the $\mathrm{Cp}^{*} \mathrm{MoO}_{2}\left(\mathrm{H}_{2} \mathrm{O}\right)_{\mathrm{x}}{ }^{+}$ion at low $\mathrm{pH}$ over a shorter time scale have systematically resulted in the formation of $\mathrm{Cp}^{*}{ }_{2} \mathrm{Mo}_{2} \mathrm{O}_{5}$. Our strategy consisted in the diffusion of a liquid (e.g. methanol) perceived as having poor solvent properties with respect to salts, into a solution containing the $\mathrm{Cp}^{*} \mathrm{MoO}_{2}\left(\mathrm{H}_{2} \mathrm{O}\right)_{\mathrm{x}}{ }^{+}$ion and a suitable counterion. However, the solubility product of compound $\mathrm{Cp}^{*}{ }_{2} \mathrm{Mo}_{2} \mathrm{O}_{5}$ (as a weak electrolyte generating $\mathrm{Cp} * \mathrm{MoO}_{2}\left(\mathrm{H}_{2} \mathrm{O}\right)_{\mathrm{x}}{ }^{+}$and $\left.\mathrm{Cp}^{*} \mathrm{MoO}_{3}{ }^{-}\right)$must be very low and the very low concentration of $\mathrm{Cp}^{*} \mathrm{MoO}_{3}{ }^{-}$in equilibrium with the cation at $\mathrm{pH} 1$ (the $\mathrm{pK}_{\mathrm{a}}$ of $\mathrm{Cp}^{*} \mathrm{MoO}_{2}(\mathrm{OH})$ is 3.65) is sufficient to precipitate the molecular compound. Future efforts at experimentally determining the number of coordinated water ligands in $\mathrm{Cp}^{*} \mathrm{MoO}_{2}\left(\mathrm{H}_{2} \mathrm{O}\right)_{\mathrm{x}}{ }^{+}$will focus on NMR spectroscopy.

\section{Conclusions}

Our systematic investigation of the aqueous chemistry of $\mathrm{Cp}^{*} \mathrm{Mo}^{\mathrm{VI}}$ has led to the serendipitous discovery and then to a simple, selective and high-yield synthesis of the organometallic polyoxomolybdate $\mathrm{Cp}^{*}{ }_{2} \mathrm{Mo}_{6} \mathrm{O}_{17}$. This compound is a new member of a relatively small class of cyclopentadienyl containing polyoxometallates, which includes $\left[\mathrm{CpTiM}_{5} \mathrm{O}_{18}\right]^{3-}(\mathrm{M}=\mathrm{Mo}, \mathrm{W}),{ }^{[35]}\left[\mathrm{Cp}^{*} \mathrm{Mo}_{6} \mathrm{O}_{18}\right]^{-[29,},{ }^{30]}$ and $\mathrm{Cp}_{2}{ }_{2} \mathrm{~W}_{2} \mathrm{O}_{17 .}{ }^{[31]}$ The synthetic method shown in Equation 1 can probably be extended to the synthesis of a wide range of organometallic homo- and heteronuclear polyoxometallates. 
Supplementary material. Crystallographic data (atomic coordinates, thermal parameters, full lists of bond distances and angles) have been deposited at the Cambridge Crystallographic Data Centre, CCDC No. 231765. Copies of the data can be obtained free of charge from CCDC, 12 Union Road, Cambridge CB2 1EZ, UK (fax: +44-1223-336033; e-mail: deposit@ccdc.com.ac.uk or www: http://www.ccdc.cam.ac.uk).

Acknowledgements. We are grateful to the European Commission for support of this work through the Research Training Network "AQUACHEM" (contract No. MRTN-CT-2003503864). The European COST D29 programme (working group 0009-03) and CNRS are also acknowledged for additional financial help. We thank J. Jaud of CEMES (Toulouse) for recording the X-ray powder diffraction pattern of compound $\mathrm{Cp}^{*}{ }_{2} \mathrm{Mo}_{6} \mathrm{O}_{17}$ and Prof. S. Alvarez for the calculation of the octahedral symmetry measures and for sending us a preprint of ref. [37] prior to publication.

\section{References}

[1] T. Chan, L. Li, Y. Yang, W. Lu, ACS Symp. Ser. 2002, 819, 166-177.

[2] F. Joó, Acc. Chem. Res. 2002, 35, 738-745.

[3] I. T. Horvath, Acc. Chem. Res. 2002, 35, 685.

[4] D. Sinou, Topics Curr. Chem. 1999, 206, 41-59.

[5] D. Sinou, Adv. Synth. Catal. 2002, 344, 221-237.

[6] G. E. Jaouen (Ed.), J. Organomet. Chem. (special issue: bioorganometallic chemistry) 1999, 589.

[7] P. Kalck, F. Monteil, Adv. Organometal. Chem. 1992, 34, 219-284.

[8] B. E. Hanson, Coord. Chem. Rev. 1999, 186, 795-807.

[9] C. Muller, D. Vos, P. Jutzi, J. Organometal. Chem. 2000, 600, 127-143.

[10] W. A. Herrmann, E. Herdtweck, M. Flöel, J. Kulpe, U. Küsthardt, J. Okuda, Polyhedron 1987, 6, 1165-1182.

[11] W. A. Herrmann, Comments Inorg. Chem. 1988, 7, 73-107.

[12] M. Cousins, M. L. H. Green, J. Chem. Soc. 1964, 1567-1572.

[13] M. Cousins, M. L. H. Green, J. Chem. Soc. (A) 1969, 16-19.

[14] W. A. Herrmann, F. E. Kühn, Acc. Chem. Res. 1997, 30, 169-180.

[15] R. Poli, Chem. Eur. J. 2004, 10, 332-341.

[16] E. Collange, J. Garcia, R. Poli, New J. Chem. 2002, 26, 1249-1256. 
[17] J. Gun, A. Modestov, O. Lev, D. Saurenz, M. A. Vorotyntsev, R. Poli, Eur. J. Inorg. Chem. 2003, 482-492.

[18] J. Gun, A. Modestov, O. Lev, R. Poli, Eur. J. Inorg. Chem. 2003, 2264-2272.

[19] F. Demirhan, J. Gun, O. Lev, A. Modestov, R. Poli, P. Richard, J. Chem. Soc, Dalton Trans. 2002, 2109-2111.

[20] F. Demirhan, P. Richard, R. Poli, Inorg. Chim. Acta 2003, 347, 161-166.

[21] M. S. Rau, C. M. Kretz, L. A. Mercando, G. L. Geoffroy, A. L. Rheingold, J. Am. Chem. Soc. 1991, 113, 7420-7421.

[22] M. S. Rau, C. M. Kretz, G. L. Geoffroy, A. L. Rheingold, Organometallics 1993, 12, 3447-3460.

[23] J. Sundermeyer, U. Radius, C. Burschka, Chem. Ber. 1992, 125, 2379-2384.

[24] D. Saurenz, F. Demirhan, P. Richard, R. Poli, H. Sitzmann, Eur. J. Inorg. Chem. 2002, 1415-1424.

[25] G. M. Sheldrick, SHELXS97. Program for Crystal Structure solution, University of Göttingen, Göttingen, Germany, 1997.

[26] G. M. Sheldrick, SHELXL97. Program for Crystal Structure refinement, University of Göttingen, Göttingen, Germany, 1997.

[27] L. J. Farrugia, J. Appl. Crystallogr. 1999, 32, 837-838.

[28] P. Gouzerh, A. Proust, Chem. Rev. 1998, 98, 77-111.

[29] F. Bottomley, J. Chen, Organometallics 1992, 11, 3404-3411.

[30] A. Proust, R. Thouvenot, P. Herson, J. Chem. Soc., Dalton Trans. 1999, 51-55.

[31] J. R. Harper, A. L. Rheingold, J. Am. Chem. Soc. 1990, 112, 4037-4038.

[32] H. Allcock, E. Bissell, E. Shawl, Inorg. Chem. 1973, 12, 2963-2968.

[33] C. Garner, N. Howlader, A. Mcphail, R. Miller, K. Onan, F. Mabbs, J. Chem. Soc., Dalton Trans. 1978, 1978, 1582-1589.

[34] J. Fuchs, K. F. Jahr, Z. Naturforsch., B: Chem. Sci. 1968, 23, 1380.

[35] T. M. Che, V. W. Day, L. C. Francesconi, M. F. Fredrich, W. G. Klemperer, W. Shum, Inorg. Chem. 1985, 24, 4055-4062.

[36] S. Alvarez, D. Avnir, M. Llunell, M. Pinsky, New J. Chem. 2002, 26, 996-1009.

[37] D. Casanova, J. Cirera, M. Llunell, P. Alemany, D. Avnir, S. Alvarez, J. Am. Chem Soc. 2004, 126, 1755-1763. 


\section{Captions for Figures.}

Figure 1. Powder diffraction spectrum of compound $\mathrm{Cp}^{*}{ }_{2} \mathrm{Mo}_{6} \mathrm{O}_{17}$ obtained from $\mathrm{Cp}^{*}{ }_{2} \mathrm{Mo}_{2} \mathrm{O}_{5}$ and $\mathrm{MoO}_{4}{ }^{2-}$. The circle show the diffractions that have been correctly indexed on the basis of the single crystal unit cell (see Table 3).

Figure 2. An ORTEP view of the $\mathrm{Cp}^{*}{ }_{2} \mathrm{Mo}_{6} \mathrm{O}_{17}$ molecule. 
Table 1. Crystal data and structure refinement for compound $\mathrm{Cp}^{*}{ }_{2} \mathrm{Mo}_{2} \mathrm{O}_{17}$.

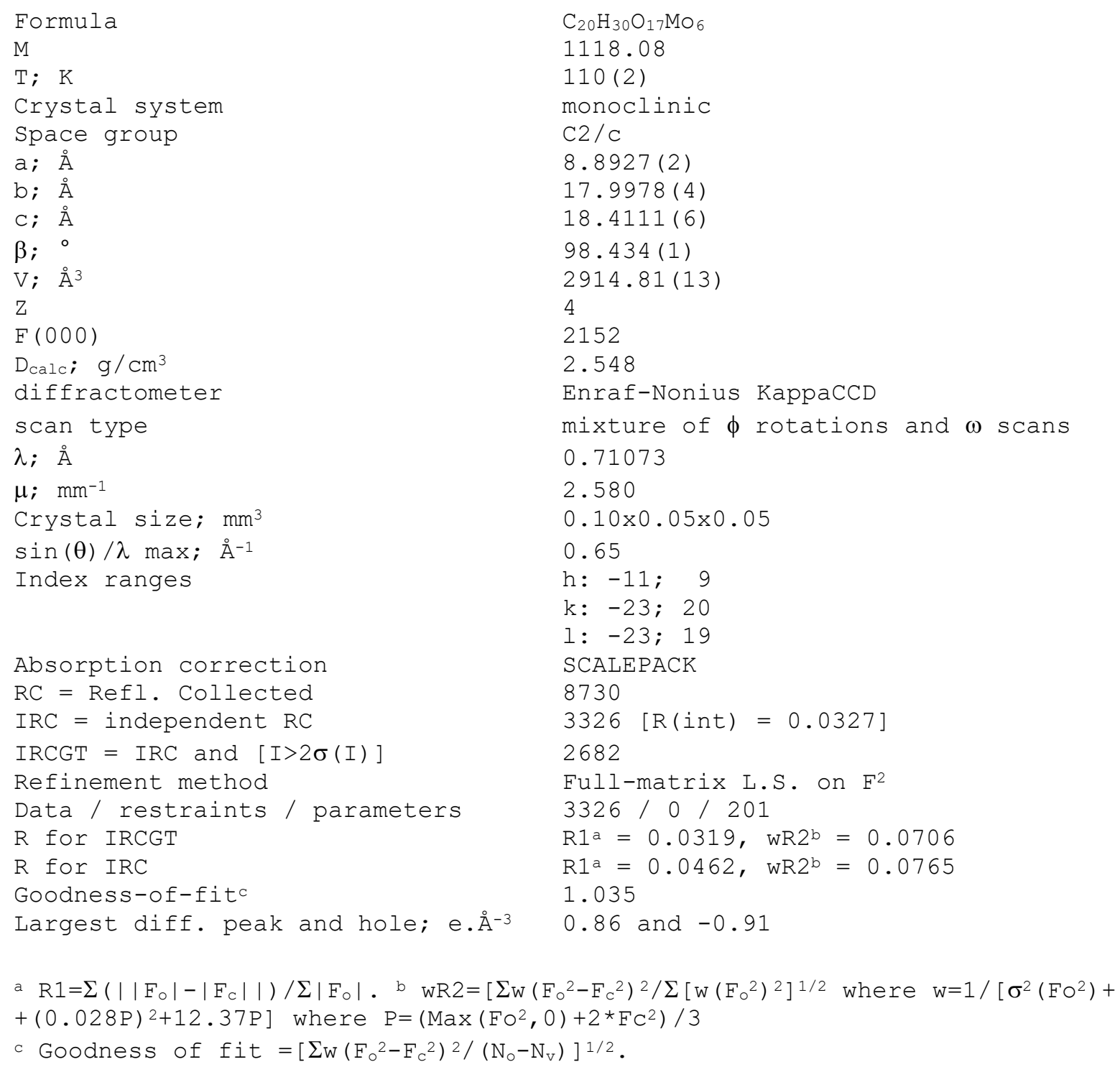


Table 2. Selected bond lengths $[\AA]$ and angles $\left[{ }^{\circ}\right]$ for compound $\mathrm{Cp}^{*}{ }_{2} \mathrm{Mo}_{2} \mathrm{O}_{17}{ }^{\text {a }}$

\begin{tabular}{|c|c|}
\hline Mo (1)-Ct & $2.109(5)$ \\
\hline Mo (1) -O (1) & $2.145(2)$ \\
\hline $\operatorname{Mo}(1)-O(2)$ & $2.029(3)$ \\
\hline Mo (1) -O (3) & $1.955(3)$ \\
\hline Mo (1) -O (5) & $1.9430(19)$ \\
\hline $\operatorname{Mo}(1)-O(6)$ & $1.890(3)$ \\
\hline $\operatorname{Mo}(2)-O(7)$ & $1.683(3)$ \\
\hline $\operatorname{Mo}(2)-O(1)$ & $2.3674(5)$ \\
\hline $\operatorname{Mo}(2)-O(2)$ & $1.855(3)$ \\
\hline $\operatorname{Mo}(2)-O(4)$ & $1.871(3)$ \\
\hline $\operatorname{Mo}(2)-O(6) \#$ & $1.980(3)$ \\
\hline $\operatorname{Mo}(2)-O(10) \#$ & $2.006(3)$ \\
\hline $\operatorname{Mo}(3)-O(9)$ & $1.687(3)$ \\
\hline $\operatorname{Mo}(3)-O(1)$ & $2.542(3)$ \\
\hline $\operatorname{Mo}(3)-O(3)$ & $1.883(3)$ \\
\hline $\operatorname{Mo}(3)-O(4)$ & $1.977(3)$ \\
\hline $\operatorname{Mo}(3)-O(8)$ & $1.9159(17$ \\
\hline $\operatorname{Mo}(3)-O(10)$ & $1.861(3)$ \\
\hline $\operatorname{Mo}(1)-O(1)-\operatorname{Mo~(3)~\# ~} 1$ & $172.33(12)$ \\
\hline $\operatorname{Mo}(1)-\mathrm{O}(1)-\mathrm{Mo}(1) \#$ & $97.78(14)$ \\
\hline $\operatorname{Mo}(1)-O(1)-\operatorname{Mo}(2)$ & $93.81(5)$ \\
\hline $\operatorname{Mo}(1)-O(1)-\operatorname{Mo}(2) \#$ & $93.68(5)$ \\
\hline $\operatorname{Mo}(2)-\mathrm{O}(1)-\mathrm{Mo}(2) \#$ & $168.60(17)$ \\
\hline $\operatorname{Mo}(2)-\mathrm{O}(2)-\mathrm{Mo}(1)$ & $116.19(13)$ \\
\hline Mo (3) -O (3) -Mo (1) & $119.93(15)$ \\
\hline $\operatorname{Mo}(2)-O(4)-\operatorname{Mo~(3)~}$ & $119.76(14)$ \\
\hline $\mathrm{Mo}(1) \#-\mathrm{O}(5)-\mathrm{Mo}(1)$ & $112.56(17)$ \\
\hline $\operatorname{Mo}(1)-O(6)-\operatorname{Mo}(2) \#$ & $116.75(13)$ \\
\hline $\operatorname{Mo~(3)~\# -O~(~} 8$ ) -Mo (3) & $121.97(18)$ \\
\hline $\operatorname{Mo}(3)-O(10)-\operatorname{Mo}(2) \#$ & $120.26(14)$ \\
\hline Ct-Mo (1) -O (1) & $178.82(13)$ \\
\hline $\mathrm{Ct}-\mathrm{Mo}(1)-\mathrm{O}(2)$ & $104.62(15)$ \\
\hline Ct-Mo (1) -O (3) & $102.19(15)$ \\
\hline $\mathrm{Ct}-\mathrm{Mo}(1)-\mathrm{O}(5)$ & $104.03(16)$ \\
\hline $\mathrm{Ct}-\mathrm{Mo}(1)-\mathrm{O}(6)$ & $101.51(15)$ \\
\hline $\mathrm{O}(6)-\mathrm{Mo}(1)-\mathrm{O}(5)$ & $91.07(8)$ \\
\hline $\mathrm{O}(6)-\mathrm{Mo}(1)-\mathrm{O}(3)$ & $88.94(11)$ \\
\hline $\mathrm{O}(5)-\mathrm{Mo}(1)-\mathrm{O}(3)$ & $153.22(12)$ \\
\hline $\mathrm{O}(6)-\mathrm{Mo}(1)-\mathrm{O}(2)$ & $153.75(11)$ \\
\hline $\mathrm{O}(5)-\mathrm{Mo}(1)-\mathrm{O}(2)$ & $85.03(8)$ \\
\hline $\mathrm{O}(3)-\mathrm{Mo}(1)-\mathrm{O}(2)$ & $83.25(11)$ \\
\hline $\mathrm{O}(6)-\mathrm{Mo}(1)-\mathrm{O}(1)$ & $78.26(8)$ \\
\hline $\mathrm{O}(5)-\mathrm{Mo}(1)-\mathrm{O}(1)$ & $74.83(11)$ \\
\hline $\mathrm{O}(3)-\mathrm{Mo}(1)-\mathrm{O}(1)$ & $78.97(10)$ \\
\hline $\mathrm{O}(2)-\mathrm{Mo}(1)-\mathrm{O}(1)$ & $75.67(8)$ \\
\hline $\mathrm{O}(7)-\mathrm{Mo}(2)-\mathrm{O}(2)$ & $106.89(13)$ \\
\hline $\mathrm{O}(7)-\mathrm{Mo}(2)-\mathrm{O}(4)$ & $105.67(13)$ \\
\hline $\mathrm{O}(2)-\mathrm{Mo}(2)-\mathrm{O}(4)$ & $93.30(12)$ \\
\hline $\mathrm{O}(7)-\mathrm{Mo}(2)-\mathrm{O}(6) \#$ & $102.31(13)$ \\
\hline $\mathrm{O}(2)-\mathrm{Mo}(2)-\mathrm{O}(6) \#$ & $86.52(12)$ \\
\hline $\mathrm{O}(4)-\mathrm{Mo}(2)-\mathrm{O}(6) \#$ & $150.77(11)$ \\
\hline $\mathrm{O}(7)-\mathrm{Mo}(2)-\mathrm{O}(10) \#$ & $101.54(13)$ \\
\hline
\end{tabular}




\begin{tabular}{|c|c|}
\hline $\mathrm{O}(2)-\mathrm{Mo}(2)-\mathrm{O}(10) \#$ & $150.83(12)$ \\
\hline $\mathrm{O}(4)-\mathrm{Mo}(2)-\mathrm{O}(10) \#$ & $85.16(11)$ \\
\hline $\mathrm{O}(6) \#-\mathrm{Mo}(2)-\mathrm{O}(10) \#$ & $81.11(11)$ \\
\hline $\mathrm{O}(7)-\mathrm{Mo}(2)-\mathrm{O}(1)$ & $173.62(11)$ \\
\hline $\mathrm{O}(2)-\mathrm{Mo}(2)-\mathrm{O}(1)$ & $73.58(11)$ \\
\hline $\mathrm{O}(4)-\mathrm{Mo}(2)-\mathrm{O}(1)$ & $80.59(10)$ \\
\hline $\mathrm{O}(6) \#-\mathrm{Mo}(2)-\mathrm{O}(1)$ & $71.32(10)$ \\
\hline $\mathrm{O}(10) \#-\mathrm{Mo}(2)-\mathrm{O}(1)$ & $77.44(9)$ \\
\hline $\mathrm{O}(9)-\mathrm{Mo}(3)-\mathrm{O}(10)$ & $105.45(13)$ \\
\hline $\mathrm{O}(9)-\mathrm{Mo}(3)-\mathrm{O}(3)$ & $105.95(13)$ \\
\hline $\mathrm{O}(10)-\mathrm{Mo}(3)-\mathrm{O}(3)$ & $88.80(12)$ \\
\hline $\mathrm{O}(9)-\mathrm{Mo}(3)-\mathrm{O}(8)$ & $105.63(13)$ \\
\hline $\mathrm{O}(10)-\mathrm{Mo}(3)-\mathrm{O}(8)$ & $88.02(9)$ \\
\hline $\mathrm{O}(3)-\mathrm{Mo}(3)-\mathrm{O}(8)$ & $147.95(12)$ \\
\hline $\mathrm{O}(9)-\mathrm{Mo}(3)-\mathrm{O}(4)$ & $104.80(13)$ \\
\hline $\mathrm{O}(10)-\mathrm{Mo}(3)-\mathrm{O}(4)$ & $149.74(11)$ \\
\hline $\mathrm{O}(3)-\mathrm{Mo}(3)-\mathrm{O}(4)$ & $83.77(12)$ \\
\hline $\mathrm{O}(8)-\mathrm{Mo}(3)-\mathrm{O}(4)$ & $83.10(8)$ \\
\hline
\end{tabular}

${ }^{a}$ Symmetry transformations used to generate equivalent atoms: $\#-\mathrm{x}+1, \mathrm{y},-\mathrm{z}+1 / 2 ; \mathrm{Ct}=\mathrm{Cp} *$ ring centroid. 
Table 3. Comparison between experimental (hkl) reflections for the powdered sample and the corresponding calculated reflections from the single crystal data.

\begin{tabular}{cccccc}
\hline $\mathrm{h}$ & $\mathrm{k}$ & 1 & $2 \theta$ (obs.) & $2 \theta$ (calc.) & $\Delta(2 \theta)$ \\
\hline 0 & 2 & 0 & 9.7362 & 9.7495 & 0.0133 \\
0 & 2 & 1 & 10.9172 & 10.8865 & -0.0307 \\
-1 & 1 & 0 & 11.2333 & 11.2073 & -0.0260 \\
-1 & 1 & 1 & 11.6057 & 11.5951 & -0.0107 \\
1 & 1 & 1 & 12.7986 & 12.7973 & -0.0012 \\
0 & 2 & 2 & 13.7702 & 13.7504 & -0.0199 \\
1 & 3 & 1 & 18.8771 & 18.8665 & -0.0107 \\
1 & 1 & 3 & 19.5518 & 19.5597 & 0.0079 \\
2 & 0 & 0 & 20.2344 & 20.2545 & 0.0201 \\
-1 & 4 & 1 & 21.1031 & 21.1041 & 0.0010 \\
-1 & 3 & 1 & 22.0832 & 22.0729 & -0.0103 \\
-2 & 2 & 2 & 23.3041 & 23.3110 & 0.0069 \\
1 & 3 & 3 & 24.0060 & 24.0194 & 0.0133 \\
0 & 5 & 0 & 24.5094 & 24.5313 & 0.0219 \\
-1 & 3 & 4 & 25.3254 & 25.3053 & -0.0201 \\
-2 & 0 & 4 & 25.9693 & 25.9695 & 0.0002 \\
-1 & 5 & 1 & 26.7528 & 26.7553 & 0.0025 \\
1 & 5 & 1 & 27.3104 & 27.3140 & 0.0036 \\
1 & 0 & 5 & 27.7927 & 27.7974 & 0.0047 \\
1 & 1 & 5 & 28.2441 & 28.2377 & -0.0064 \\
-2 & 4 & 2 & 28.9317 & 28.9499 & 0.0182 \\
0 & 0 & 6 & 29.3072 & 29.3026 & -0.0046 \\
0 & 2 & 6 & 30.9357 & 30.9514 & 0.0157 \\
2 & 5 & 0 & 32.0447 & 32.0161 & -0.0285 \\
-2 & 0 & 6 & 33.1946 & 33.1954 & 0.0008 \\
-2 & 2 & 6 & 34.6695 & 34.6777 & 0.0082 \\
\hline & & & & &
\end{tabular}


Figure 1

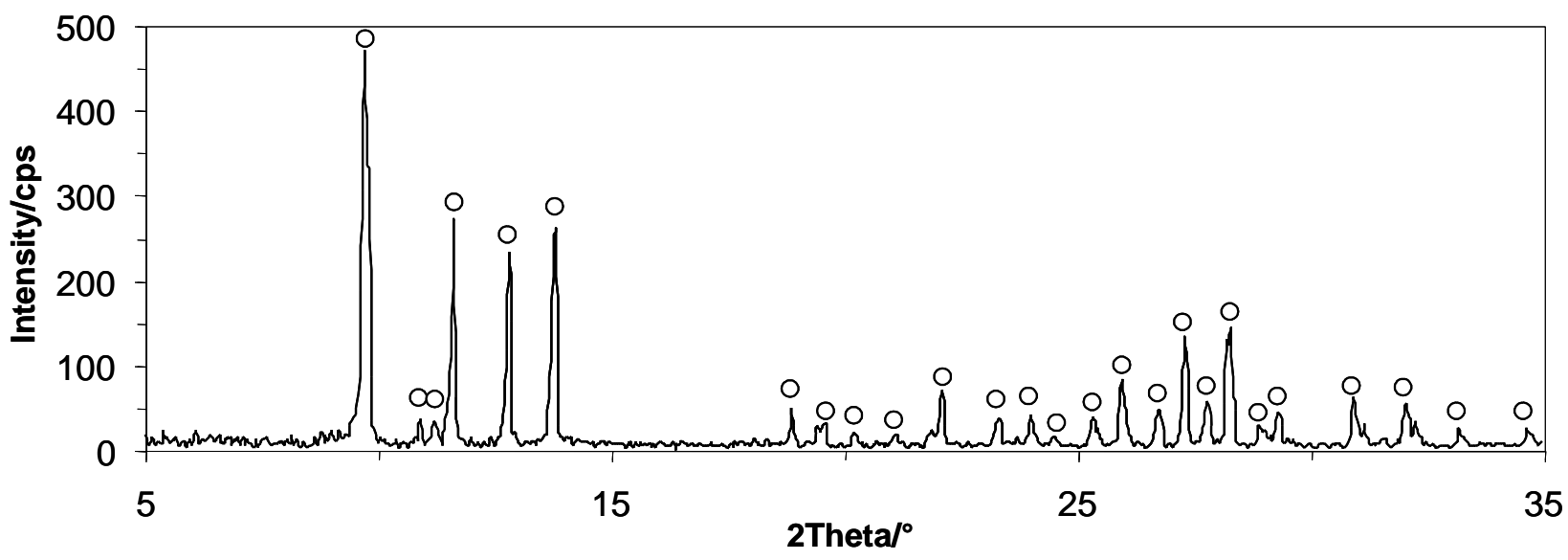


Figure 2.

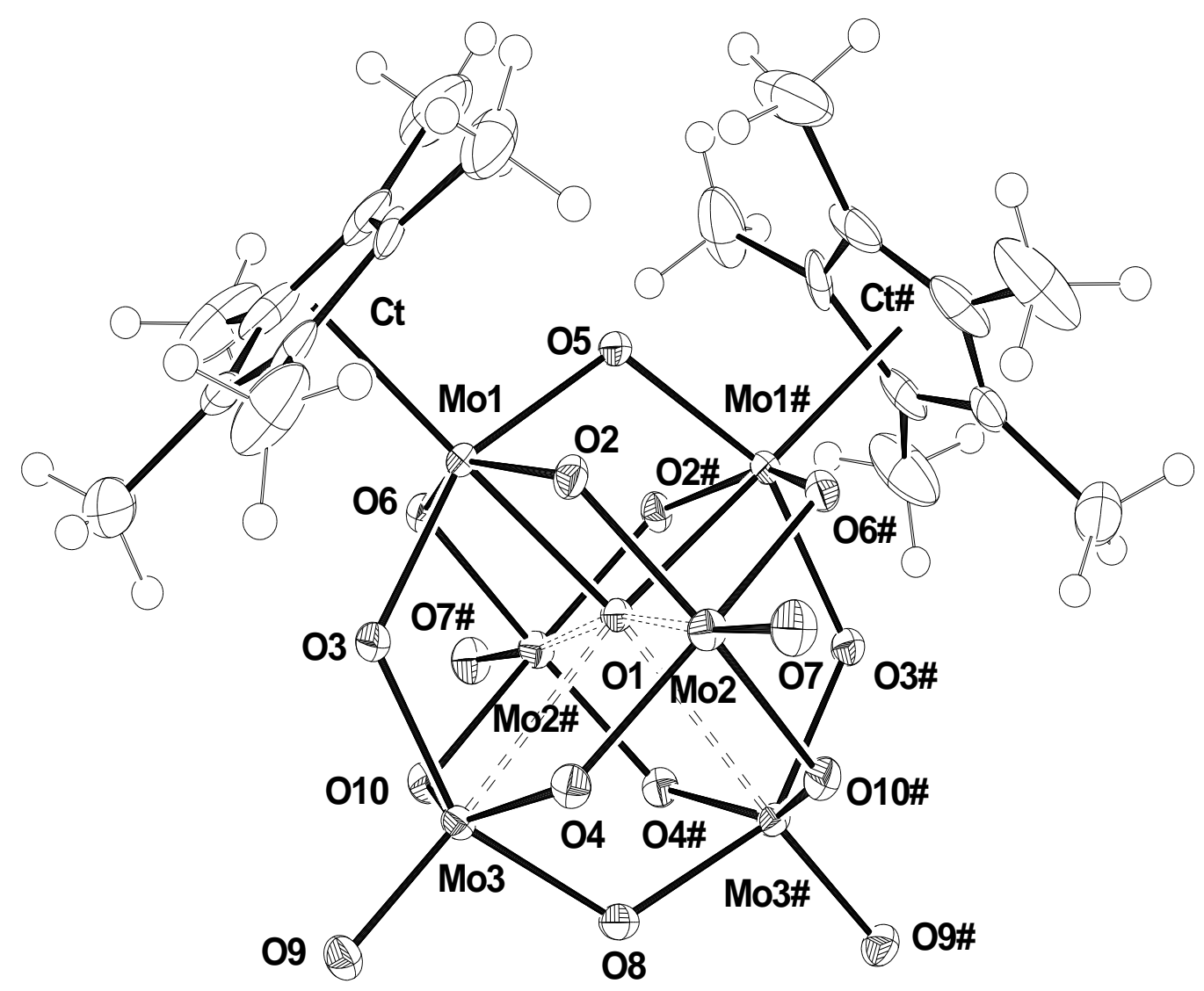

